with steroid synthesis. Its lack of biochemical information will make it of little interest to those whose studies are more biological : for them it will not replace 'Steroids' by Fieser and Fieser. All aspects of production are first class.

\section{Essays on Nucleic Acids}

Erwin Chargaff. Pp. xii +21 I, illustrated. Amsterdam, London and New York: Elsevier Publishing Co. 1963. 45s.

This series of essays consists of the texts of some of the lectures and writings of Professor Chargaff between the years of 1949 and 1962 and covers most of the modern history of nucleoproteins and nucleic acids. The author is, of course, one of the pioneers in the field and was responsible for the first demonstration of base pairing in DNA. When he started his work on nucleic acids little was known about them. The tetranucleotide theory was still fashionable and the qualitative composition of only two nucleic acids was known. However, there was a new wave of interest in these compounds as a result of the work of Brachet and Caspersson on the high nucleic acid content of cells rapidly metabolizing proteins and of Avery's demonstration of transformation of bacterial types by DNA preparations.

Professor Chargaff is an amusing writer and these essays are very readable. It is fascinating to trace the evolution of ideas on nucleic acids during the 13 years between the first and last article. Throughout, the author is concerned with repeated warnings against facile simplification of the subject and over-imaginative speculation. His feelings about this are summed up in the last chapter entitled 'Amphisbæna' ('a fabled serpent with a head at each end, moving either way'), in which he records an imaginary discussion between an old chemist and a young molecular biologist. The author's own opinions are put into the mouth of the old chemist, who, it must be admitted, is given more space in which to express his views than his opponent, who represents the credulous young worker in the field who acclaims each new theory as a great truth. Since most of the ideas in this section have already been expressed in other essays, the chapter could possibly have been shorter.

This book is of great interest to anyone interested in nucleic acids and in the history of the gradual elucidation of their structure.

\section{Molecular Biophysics}

Richard B. Setlow and ERnest C. Pollard. Pp. xiii +545 , illustrated. Oxford, New York, London and Paris: Pergamon Press. I962. 84s.

This book mainly deals with those aspects of biophysics which attempt to explain biological phenomena in terms of the properties of molecules. The authors say that the standard is suitable for senior or final year students. A wide scientific knowledge is presupposed, although the authors claim that the text has been so designed that students whose knowledge is deficient in certain aspects can work through the book. It is perhaps over-optimistic to assume that a student who has to consult the diagram illustrating the elementary theory of the microscope will be able to tackle the numerical examples on the phase contrast microscope which appear 34 pages later.

The first part of the book describes the general characteristics of cells and applies thermodynamic concepts and information theory to elucidate the properties of living matter. The next part describes methods which are used to determine molecular structure. Then follows a section on such topics as the action of $\mathrm{X}$-rays on cells and information which may be deduced therefrom aboat the cell. The book ends with a description of muscle nerve and eye function and with some speculations intra-cellular processes.

The authors are not afraid of working out the numerica consequences of their speculations, and even if the prove in the future to be completely wrong, this does not detract from the profound mental stimulation that the book affords today.

The book gives a very clear idea of the number $\overline{\bar{a} f}$ scientific disciplines which are being used to elucidafe the problems of living matter and is confidently to be recommended.

The EMG. A Guide and Atlas for Practical Electromyography

Forbes H. Norris, JR. Pp. viii + I34, 4I illưgig trations. New York and London: Grune 8 Stratton. 1963. $\$ 4.75$.

In the Preface of the book under review it is stated that "It would seem to answer the need for a simpte explanation of electromyography'. This statement can unhesitatingly be endorsed. Written simply and clearbo, it provides a good introduction into the basic principles and the practice of this method. Twenty-two pages devoted to a description of instrumentation and artifacis, 64 pages to EMG findings (natural and evoked potêftials), interpretation and examination. A discussion $\$ \mathrm{f}$ Io illustrative cases and a short chapter on strengthduration curves conclude the book. The newcomer will find much useful information about the technien side, including a detailed description of the recording equipment used by the author. Throughout the book the necessity of correlating the EMG with clifige findings is rightly stressed. The limitations as well to the value of the method are clearly set out. The tinge of normal and abnormalities in some common newogenic and muscular diseases are described and illutrated by informative tracings. Special mention may be made of some useful tables: of certain normal values; comparison of some EMG findings in certain neupgenic and muscular disorders; and the relative signifcance of EMG findings. The author's approach to the subject is didactic, constructive and yet critical. The book can be warmly recommended to those to whom it is directed: medical students, postgraduate students neurology, neurosurgery, orthopædics and psychiati, and senior clinicians trained in the pre-electromigraphic era. To those more experienced in the method the appended bibliography will prove a useful guide for further reading.

Preparation of the Physician for General Practione

Proceedings of a Conference arranged by the World Health Organization at Edinburgh in 19Q1. Pp. I 14. London: H.M.S.O. I963. 6s. $8 d$.

In 1961 the World Health Organization brou墨ht together 36 experts from European countries to discuss the problem of training the physician for his work the community. This publication includes the contributions of the principal speakers and summaries of the ensuing discussions. The title will naturally give British reader hope of finding authoritative guidapee as to the best preparation for general practice as<it exists in this country but it must be remembered that other nations have different patterns of medical capo; in consequence the World Health Organization wisely limited the scope of the Conference to the undergraduife years and did not attempt to deal with postgradurgte education, the importance of which as a preparation for general practice in Britain is being increasingly 